\title{
COPING RESPONSES AS PREDICTORS OF SATISFACTION WITH LIFE AMONGST A GROUP OF PATIENTS DIAGNOSED WITH DIABETES MELLITUS
}

\author{
Authors: \\ Chrisma Pretorius ${ }^{1}$ \\ Stephen P. Walker ${ }^{1}$ \\ Karel G.F. Esterhuyse ${ }^{2}$
}

\section{Affiliations:}

${ }^{1}$ Unit for Professional

Training and Service in the Behavioural Sciences,

University of the Free State, South Africa

${ }^{2}$ Department of Psychology, University of the Free State, South Africa

\section{Correspondence to:}

Stephen Walker

email:

walkersp@ufs.ac.za

\section{Postal address:}

UNIBS, Internal Box 10,

University of the Free State, PO Box 339, Bloemfontein 9300, South Africa

\section{Keywords:}

approach coping responses; avoidant coping responses; coping responses inventory; diabetes mellitus; satisfaction with life

\section{Dates:}

Received: 05 Nov. 2009

Accepted: 12 Aug. 2010

Published: 04 Nov. 2010

\section{How to cite this article:} Pretorius, C., Walker, S.P. \& Esterhuyse, K.G.F., 2010, 'Coping responses as predictors of satisfaction with life amongst a group of patients diagnosed with diabetes mellitus', Health $S A$ Gesondheid 15(1), Art. \#513, 5 pages. DOI: $10.4102 /$ hsag. v15i1.513

This article is available at: http:/ /www.hsag.co.za

(c) 2010. The Authors. Licensee: OpenJournals Publishing. This work is licensed under the Creative Commons Attribution License.

\section{ABSTRACT}

The purpose of this study was to investigate the extent to which coping responses could predict the level of life satisfaction experienced by patients suffering from diabetes mellitus.

A non-experimental, cross-sectional design was adopted. The sample consisted of 154 individuals (62 Type I diabetics, 80 Type II diabetics, and 12 individuals for whom diagnostic information was not available) recruited from the outpatient diabetes clinic at a large state hospital. All participants completed the Coping Responses Inventory - Adult Version, as well as the Satisfaction with Life Scale. Initially, Pearson product-moment correlation coefficients were calculated to examine the relationship between the predictor variables (coping responses) and the criterion variable (satisfaction with life). Hierarchical regression analyses were conducted to determine the amount of variance in the satisfaction with life scores that was explained by coping responses.

The combination of approach and avoidance coping subscales accounted for $33 \%$ of the variance in the participants' satisfaction with life scores. However, upon further analysis, the avoidance coping subscales were found to account for $28 \%$ of the variance in the sample's satisfaction with life. The cognitive avoidance subscale and the acceptance or resignation subscale were found to correlate negatively with satisfaction with life at the $1 \%$ level of significance.

It appears that approach coping responses do not predict the satisfaction with life experienced by individuals suffering from diabetes. However, avoidant coping responses, particularly cognitive avoidance and acceptance or resignation, are predictive of lower levels of satisfaction with life.

\section{OPSOMMING}

Die doel van hierdie navorsing was om vas te stel tot watter mate hanteringsgedrag (coping responses) die vlak van lewenstevredenheid by pasiënte wat aan diabetes ly kan voorspel.

'n Nie-eksperimentele, dwarssnit ontwerp is gebruik. Die steekproef het uit 154 individue (62 Tipe I-diabetes, 80 Tipe II-diabetes en 12 individue waarvan die diagnostiese inligting nie beskikbaar was nie) bestaan, wat van die buitepasiënte kliniek by 'n groot staatshospitaal verkry is. Alle deelnemers het die Coping Responses Inventory - Adult Version, sowel as die Satisfaction with Life Scale voltooi. Aanvanklik is die Pearson produkmoment korrelasie koëffisiënte bereken om die verhouding tussen die voorspeller-veranderlikes (coping responses/hanteringsgedrag) en die kriterium-veranderlike (satisfaction with life/lewenstevredenheid) te ondersoek. Hiërargiese regressie-analise is uitgevoer om die hoeveelheid variansie in die lewenstevredenheid-telling wat deur hanteringsgedrag verklaar is, te bepaal.

Die kombinasie van approach en avoidance coping subscales het $33 \%$ van die variansie in die deelnemers se Lewenstevredenheid-telling verklaar. Na verdere ontleding is egter gevind dat die avoidance coping subscales $28 \%$ van die variansie in die lewenstevredenheid van die steekproef verklaar het. Daar is gevind dat die cognitive avoidance subscale en die acceptance or resignation subscale negatief op die $1 \%$ peil van betekenisvolheid met lewenstevredenheid korreleer.

Dit blyk dat toenaderings (approach coping responses) nie die lewenstevredenheid by individue wat aan diabetes ly, voorspel nie. Vermydingsgedrag (avoidant coping responses), in besonder kognitiewe vermyding en aanvaarding of berusting, is egter voorspellend van laer vlakke van lewenstevredenheid.

\section{INTRODUCTION}

Diabetes mellitus is a chronic disease that requires several adjustments in the patient's lifestyle and has been described as the 'most complex and demanding of any chronic disease to manage' (Sridhar \& Madhu 2002:1556). Diabetes was estimated to have accounted for 987000 deaths $(1.7 \%$ of global mortality) in 2002 (Roglic et al. 2005). Furthermore, the chronic nature of diabetes, the frequency of diabetes-related complications and the resultant frequent use of health care services by patients suffering from diabetes place a significant burden on national economies worldwide (Rowley 1999; Spollett 2006; Willoughby et al. 2000). Given the fact that diabetes is incurable and has to be controlled through the use of insulin, diet and exercise, the onus rests on the patient to adapt successfully to the diagnosis and to adhere to strict treatment and self-management protocols (Sriram, Sridhar \& Madhu 2001). Patients following a diabetes management regimen are faced with psychological and behavioural challenges that differ from those faced by sufferers of many other chronic illnesses (Sriram, Sridhar \& Madhu 2001). Individuals suffering from diabetes are thus at increased risk of psychological distress, including anxiety and mood disorders (Delamater et al. 2001; Sacco \& Yanover 2006; Sperry 2006).

Holistic management of diabetes requires that adequate attention be paid not only to the prevalence of psychiatric symptomatology amongst diabetes patients, but that subclinical indicators of distress, 
such as patients' levels of life satisfaction, be taken into account. However, given that sufferers do not exhibit uniform psychological reactions to living with this chronic condition, it may be suggested that intra-individual factors, such as predispositions to psychopathology and coping strategies, could, to some extent, affect the individual's reaction to the challenges posed by the disease. It seems that coping plays a mediatory role in the emotional outcome of stressful events (Lazarus 1993; Moos \& Holahan 2003). An individual's cognitive appraisal (challenge or threat, potential harm or benefit) of an encounter acts as a mediator between life stressors and coping responses of the person (Lazarus \& Folkman 1987). A chronic illness such as diabetes may be viewed as 'a major stressful life event which is characterised by a number of recurring stressful situations that pose serious challenges to adaptation' (Heijmans et al. 2004:256). Whereas Lazarus and Folkman's meta-theory (1987) of stress appraisal and coping provides a broad overview of coping as a process comprising cognitive appraisal and possible stress reaction, Moos and Holahan (2003) explore the different coping responses that are employed on an individual level. According to the latter framework, there are generally two main dimensions used to classify the coping responses that individuals may implement in such stressful situations as the diagnosis and management of diabetes (Moos \& Holahan 2003). An individual may approach the problem by making use of active problem-solving strategies to resolve the problem (approach coping), or focus on avoidance and management of emotions associated with the problem (avoidance coping). Cognitive approach coping, such as planning, problem-solving and positive reappraisal, is associated with decreases in negative emotions and lower incidence of psychiatric symptoms (Lazarus 1993; Moos \& Holahan 2003). Conversely, avoidance coping responses, such as distancing, distraction and emotional venting, have been associated with higher levels of distress and an increase in major depressive and anxiety symptomatology (Lazarus 1993; Moos \& Holahan 2003). One study relates satisfaction with life to the achievement of vital goals in all areas of life, such as the effective management of daily life, social interaction and occupational and leisure time activities (Snellman \& Wikblad 2006). These researchers hypothesise that patients who primarily make use of avoidance coping tend to restructure their vital goals in an attempt to reduce failure and disappointment, thereby decreasing their satisfaction with life. In contrast, another study found that a positive relationship exists between problem-focused coping and an improvement in quality of life (Rose et al. 2002).

The preceding review of the literature would appear to suggest that, as a chronic disease resulting in significant lifestyle changes, diabetes confronts patients with specific stressors. These stressors may result in numerous forms of psychopathology, but more frequently have a negative effect on individual patients' perceptions of how satisfying their life is. Moreover, it is also apparent that different coping responses may influence the subjective perception that patients have of their quality of life. Consequently, a greater understanding of the interaction between coping and psychosocial functioning amongst individuals suffering from diabetes appears to be a worthwhile avenue of investigation. Therefore, this study aims to determine whether coping responses predict a significant percentage of variance in satisfaction with life experienced by a group of individuals diagnosed with diabetes mellitus.

\section{RESEARCH DESIGN AND METHODS}

\section{Design}

A non-experimental, cross-sectional design was used.

\section{Sample}

A sample of 154 diabetes patients was drawn from a weekly diabetes clinic at a local, regional tertiary hospital. Generally, the clinic provides out-patient follow-up and monitoring services to individuals within the local community suffering from diabetes. Accidental (non-probability) sampling was used to draw the sample. All patients 18 years of age and older who visited the clinic between January and August 2007 were approached to participate in the study, irrespective of the type of diabetes (Type I or Type II) from which they suffered and the eventual sample comprised 81 females $(53 \%)$. The average age of the respondents was reported to be 51.97 years, with a standard deviation of 17.54 years. The home language of most $(104 ; 68 \%)$ participants was Afrikaans, while that of 17 (11\%) was English, with the remaining $33(21 \%)$ reporting that neither Afrikaans nor English was their home language. Of the respondents, 80 (52\%) had been diagnosed with Type II diabetes and $62(40 \%)$ with Type I diabetes, while 12 participants $(8 \%)$ failed to specify the type of diabetes from which they suffered. Of the patient sample, $36(23 \%)$ reported a comorbid diagnosis of depression, while $16(10 \%)$ claimed to have been previously diagnosed with an anxiety disorder. The mean number of years that had elapsed since initial diabetes diagnosis $(n=145)$ was reported to be 11.91 years, with a standard deviation of 9.34 years (range $=1$ year 46 years).

\section{Measuring instruments}

The following instruments were administered in either English or Afrikaans, depending upon the patient's language preference.

\section{Coping Responses Inventory - Adult}

The Coping Responses Inventory - Adult (CRI-A; Moos 1993) is a 48-item, self-report inventory. Responses are indicated on a 4-point Likert-type scale anchored by 'not at all' and 'fairly often'. The CRI-A yields scores on eight coping responses scales and total scores for approach coping responses and avoidance coping responses can be determined. Approach coping responses comprise the following (1) logical analysis, (2) positive reappraisal, (3) seeking guidance and support and (4) problem-solving, while avoidance coping responses include (1) cognitive avoidance, (2) acceptance or resignation, (3) seeking alternative rewards and (4) emotional discharge.

\section{Satisfaction with Life Scale}

The Satisfaction with Life Scale (SWLS; Diener et al. 1985) was used to determine the participants' cognitive appraisal of their overall, subjective well-being. The SWLS is a five-item, selfreport measure presented on a 7-point Likert-type scale that is anchored by 'strongly disagree' and 'strongly agree'.

The preceding measuring instruments were translated into Afrikaans via the back-translation method, permission for which was obtained from the relevant authors and distributors. Once written, informed consent had been received, participants completed the questionnaires in the clinic waiting area under the supervision of a postgraduate psychology student. Respondents thus had an opportunity to seek clarification with regard to how the questionnaires should be completed, as well as with regard to any questions they found difficult to understand.

\section{Statistical analysis}

The internal consistency of the CRI-A and the SWLS was investigated by calculating the Cronbach $\alpha$-coefficients for the eight subscales of the CRI-A (logical analysis $=0.785$; positive reappraisal $=0.739$; seeking guidance $=0.734$; problem-solving $=0.821$; cognitive avoidance $=0.721$; acceptance or resignation $=0.711$; seeking alternative rewards $=0.744$; emotional discharge $=0.713)$, as well as for the total avoidance coping score $(0.931)$, the total approach coping score $(0.873)$ and for the total score of the SWLS (0.884). It is evident that both measures demonstrate acceptable levels of internal consistency, in that the corresponding $\alpha$-coefficients exceed 0.7 (Foster \& Parker 1995). Consequently, the data gained via these questionnaires can be included confidently in further statistical analysis.

\section{Statistical procedure}

Hierarchical regression analyses were conducted in order to investigate whether the coping responses of individuals 
diagnosed with diabetes predict a significant percentage of the variance in their satisfaction with life. In this particular instance, the subscales of the CRI-A served as independent (predictor) variables, while satisfaction with life served as the dependent (criterion) variable. A hierarchical F-test was used to determine whether or not a specific variable or set of variables made a statistically significant contribution to the $\mathrm{R}^{2}$ value. The study utilised both the $5 \%$ and $1 \%$ level of significance. Statistical analyses were conducted, using the SAS computer software package (SAS Institute 2003).

\section{RESULTS AND DISCUSSION}

Descriptive statistics with regard to the dependent and independent variables for the total sample were calculated prior to the investigation of the research hypothesis. The means and standard deviations are reported in Table 1.

Means and standard deviations for the CRI-A subscales and the SWLS for this study sample of diabetes patients compare favourably with published, normative data for the measuring

TABLE 1

Means and standard deviations for the Coping Responses Inventory - Adult (CRI-A) subscales and the Satisfaction with Life Scale (SWLS) for the total sample $(n=154)$

\begin{tabular}{lll}
\hline Variables & Means $(\bar{X})$ & Standard deviations (S)
\end{tabular}

Logical analysis $\quad 9.32 \quad 4.34$

Positive reappraisal $\quad 10.45 \quad 4.20$

$\begin{array}{lll}\text { Seeking guidance } & 9.71 & 4.26\end{array}$

Problem-solving $\quad 11.26 \quad 4.52$

Cognitive avoidance $\quad 8.86 \quad 4.17$

Acceptance or resignation $\quad 7.66 \quad 4.13$

Seeking alternative rewards $\quad 8.81$

Emotional discharge $\quad 6.89 \quad 4.26$

Approach total $\quad 40.01 \quad 15.92$

Avoidance total $\quad 32.40 \quad 13.37$

Satisfaction with life $\quad 22.99 \quad 7.15$

\section{TABLE 2}

Pearson product-term inter-correlations for the total sample $(n=154)$

\begin{tabular}{ll}
\hline Predictor variable & Satisfaction with life \\
\hline Logical analysis & -0.110 \\
Positive reappraisal & -0.010 \\
Seeking guidance & 0.060 \\
Problem-solving & 0.120 \\
Cognitive avoidance & $-0.290^{\star *}$ \\
Acceptance or resignation & -0.370 \\
Seeking alternative rewards & 0.160 \\
Emotional discharge & -0.150 \\
Approach total & 0.001 \\
Avoidance total & $-0.230^{*}$ \\
\hline
\end{tabular}

${ }^{*} \rho \leq 0.05 ;{ }^{* *} \rho \leq 0.01$ according to t-test. instruments administered to other samples, including a Caucasian American group of individuals with alcohol dependency problems (Moos 1993).

Pearson product-moment correlation coefficients were calculated in order to examine the relationship between the predictor variables and satisfaction with life and the results are reflected in Table 2.

It is apparent from Table 2 that two of the avoidance coping subscales (cognitive avoidance and acceptance or resignation) correlated significantly with satisfaction with life at the $1 \%$ level; in both instances the correlation is negative. Consequently, it would appear that the higher the avoidance coping scores in the current sample, the lower the satisfaction with life scores. Furthermore, the total score for avoidance coping appears to correlate negatively with satisfaction with life at the $5 \%$ level of significance.

Hierarchical regression analyses were conducted in order to investigate the contribution of the various predictor variables to the explanation of the variance in the participants' SWLS scores and the results of the analyses are shown in Table 3.

It can be seen from Table 3 that the complete set of predictor variables accounts for $33.10 \%\left(R^{2}=0.3310\right)$ of the variance in the SWLS scores in the sample. The $\mathrm{R}^{2}$ value is significant at the $1 \%$ level $[\mathrm{F}(8 ; 100)=5.01 ; \rho<0.001]$. The combination of all four subscales of the avoidance coping scale account for a statistically significant proportion of the variance in SWLS scores at the $1 \%$ level $[\mathrm{F}(4 ; 95)=9.87]$. The associated $f$-value $(0.41)$ indicates a result that is of noteworthy practical value. The four subscales of the avoidance coping scale account for $27.64 \%$ of the variance in the SWLS scores of the participants. Conversely, the combination of all four subscales of the approach coping scale does not account for a significant percentage of the variance in the sample's SWLS scores at the 5\% level.

When the subscales of the CRI-A are examined individually, it becomes apparent that cognitive avoidance, acceptance or resignation and seeking alternative rewards all account for a significant percentage of the variance in the participants' SWLS scores at the $1 \%$ level; and that positive reappraisal accounts for a significant percentage of the variance in their SWLS scores at the $5 \%$ level. However, the corresponding $f$-values indicate that the results for cognitive avoidance and acceptance or resignation are of moderate practical value, while the contributions of seeking alternative rewards and positive reappraisal to the explanation of the variance in the sample's SWLS scores do not appear to be of any practical value. However, it is apparent from Table 2 that cognitive avoidance and acceptance or resignation display a significant negative relationship to the satisfaction with life of the sample. Consequently, it would appear as though increased use of cognitive avoidance and acceptance or resignation is

TABLE 3

Contribution of the various variables to R2 for satisfaction with life

\begin{tabular}{|c|c|c|c|c|}
\hline Variables in analyses & $R^{2}$ & Contribution to $R^{2}$ : full minus reduced model & $F$ & $f^{2}$ \\
\hline [appr] + [avoid] & 0.331 & $1-6=0.2764$ & $9.87^{\star \star}$ & 0.41 \\
\hline [appr] + cognitive avoidance & 0.190 & $2-6=0.1353$ & $16.91^{\star *}$ & 0.17 \\
\hline [appr] + acceptance or resignation & 0.242 & $3-6=0.1876$ & $23.45^{\star \star}$ & 0.25 \\
\hline [appr] + seeking alternative rewards & 0.130 & $4-6=0.0752$ & $8.36^{\star \star}$ & 0.09 \\
\hline [appr] + emotional discharge & 0.062 & $5-6=0.0073$ & 0.81 & - \\
\hline [appr] & 0.055 & - & - & - \\
\hline [avoid] + [appr] & 0.331 & $7-12=0.0623$ & 2.23 & - \\
\hline [avoid] + logical analysis & 0.269 & $8-1=0.0004$ & 0.06 & - \\
\hline [avoid] + positive reappraisal & 0.298 & $9-12=0.0291$ & $4.16^{\star}$ & 0.04 \\
\hline [avoid] + seeking guidance & 0.286 & $10-12=0.0172$ & 2.46 & - \\
\hline [avoid] + problem-solving & 0.288 & $11-12=0.0188$ & 2.69 & - \\
\hline [avoid] & 0.269 & - & - & - \\
\hline
\end{tabular}

[] indicates the set of predictors; [appr], approach coping; [avoid], avoidance coping

$*_{* *} \leq 0.01 * *^{*} \leq 0.05$ 
associated with a decrease in satisfaction with life in the current sample. Nonetheless, this effect is stated to be of only moderate practical value.

Two-tailed $t$-tests were conducted in order to determine whether the mean CRI-A subscale scores in the current sample differed significantly across gender, type of diabetes (Type I/Type II), or with regard to how much time had elapsed since the patients were first diagnosed with diabetes. A significant (at the $1 \%$ level) difference was observed between the mean scores of the men and the women's mean scores on the seeking guidance subscale of the CRI-A $(t=-2.755 ; \rho=0.007)$. However, the corresponding Cohen's $d$-coefficient (0.4) is indicative of a small effect size, and is thus not considered to be of noteworthy practical value (Steyn 1999). No significant differences in CRI-A subscale scores were found between the two types of diabetes. Yet, when the mean CRI-A subscale scores of those participants who had been diagnosed with diabetes 6 years or fewer prior to the study were compared with those of individuals who had been diagnosed 14 or more years prior to the study, a significant (at the $1 \%$ level) difference was evident between the two groups on the emotional discharge subscale $(t=2.688 ; \rho=0.009)$. Once again, however, the corresponding effect size $(d=0.19)$ was not of noteworthy practical value. Based on the results, it was not necessary to conduct additional regression analyses in order to control for the effect of gender, type of diabetes and the time elapsed since initial diagnosis within the current sample.

\section{ETHICAL CONSIDERATIONS}

Permission to conduct the study was granted by the Ethics Committee of the Faculty of Health Sciences at the University of the Free State. Informed consent was obtained from all participants prior to administration of the questionnaires. The participants were informed that the data could be published in a peer review journal, but that their anonymity was guaranteed.

\section{LIMITATIONS OF THE STUDY}

Several limitations of the current study should be noted. Firstly, it is apparent that the current sample was too small to generalise the results to the broader South African diabetes population. Secondly, convenience sampling was used rather than random sampling. Consequently, the findings of this study cannot be generalised with the same confidence as they could have been if the sample had been drawn randomly. Furthermore, a longitudinal study might have yielded a more comprehensive indication of the predictive value of different coping responses directly after the initial diagnosis and during a subsequent period of adjustment to the disease. The progression of the disease and the possibility of 'diabetes burnout' could have an effect on the use of coping responses during various stages of adjustment.

\section{RECOMMENDATIONS}

A recommended research direction could be to investigate the dispositional aspects and temporal stability of life satisfaction in individual patients. Given the existence of various cultural influences in the South African context, the inclusion of race and ethnicity as variables in future research could enhance the understanding of specific patient groups' coping responses and the role that such responses play in predicting their satisfaction with life.

\section{CONCLUSION}

The study aimed to determine whether coping responses could serve as predictors of satisfaction with life amongst individuals suffering from diabetes. In examining the correlation between coping responses (both approach and avoidance) and life satisfaction, the results suggest that, as a predictor variable, approach coping (logical analysis, seeking guidance and problem-solving) shows a negative correlation with satisfaction with life, which differs from another study that found a positive relationship between problem-focused coping and an improvement in quality of life (Rose et al. 2002). In this study, the results suggest that approach coping does not either positively or negatively influence the variance in satisfaction with life of diabetes patients significantly. The findings seem surprising, as an overview of previous research gives the impression that the engagement with approach coping would be associated with greater life satisfaction amongst diabetes patients. It would therefore, appear as though approach coping, as a whole, does not show a correlation with satisfaction with life in diabetes patients and that only positive reappraisal of the situation is considered to have a positive correlation with life satisfaction in this study. It could, furthermore, be speculated that approach coping responses, such as analysing diabetes-related problems in a logical fashion and seeking guidance from others (medical staff, family members) in solving the problems, could increase a patient's self-efficacy beliefs and cultivate a more optimistic outlook, which, in turn, could lead to an increase in overall life satisfaction. However, the results indicate that a direct link to the effect cannot be made, as the adaptive value of different coping skills is determined not only by the interaction between personal and social resources, but also by what the situation requires of the individual (Moos \& Holahan 2003). Speculation on the type of situation which requires individuals to change or to adjust their coping response would include such factors as duration of the illness and emergence of complications, together with resultant medical intervention and treatment changes. In this study, a possible explanation for the insignificant association between approach coping and life satisfaction could be that the sample might have moved past the initial phase, during which logical analysis, problem-solving and guidance seeking is used to adjust to a novel situation, such as diabetes. As indicated by the results, approach and avoidance coping could be viewed as parts of a continuum along which the diabetes patient moves as situations and life circumstances change. It could, therefore, be speculated that approach and avoidance coping responses are not necessarily opposites that cancel each other out, but are, rather, interactional parts of a whole that could be independently associated with satisfaction with life.

Conversely, the results suggest that avoidance coping, especially cognitive avoidance and acceptance or resignation, account for a significant percentage of the variance in life satisfaction that diabetes patients experience, as is shown in the negative correlation. The results correspond with those of a study which found that higher scores for the avoidance coping styles, specifically cognitive avoidance, were negatively correlated with quality of life (Coelho, Amorim \& Prata 2003).

As Moos and Holahan (2003) differentiate between cognitive and behavioural avoidance coping responses, it seems appropriate to mention that the Satisfaction with Life Scale measures primarily cognitive aspects of well-being, which show an association with the cognitive component of avoidance coping, such as cognitive avoidance. The denial of diabetes-related problems through cognitive avoidance may be associated with negative effects on health outcomes, particularly in relation to adherence to a self-care regimen, or a delay or failure to seek care from others (Madhu \& Sridhar 2001; Rowley 1999). The above would appear to be logical, in that patients who avoid thinking about their illness are less likely to adhere to a daily self-management programme, or are less likely to seek medical, occupational or social support, should diabetes-related complications arise.

From the preceding discussion it could be suggested that a cognitive-focused measuring instrument (Satisfaction with Life Scale) shows limited correlation with such behavioural efforts as emotional discharge and seeking of alternative rewards. The results suggest that venting feelings to relieve emotional tension is not significantly associated with a diabetes patient's 
level of life satisfaction, which contrasts with the finding of another study, in which the use of emotion-focused coping was associated with increased diabetes-related adjustment problems (Willoughby et al. 2000).

\section{REFERENCES}

Coelho, R., Amorim, I. \& Prata, J., 2003, 'Coping styles and quality of life in patients with non-insulin-dependent diabetes mellitus', Psychosomatics 44, 312-318.

Delamater, A.M., Jacobson, A.M., Anderson, B., Cox, D., Fisher, L., Lustman, P., Rubin, R. \& Wysocki, T., 2001, 'Psychosocial therapies in diabetes', Diabetes Care 24, 1286-1292.

Diener, E., Emmons, R.A., Larsen, R.J. \& Griffin, S., 1985, 'The satisfaction with life scale', Journal of Personality Assessment $49,71-75$.

Foster, J.J. \& Parker, I., 1995, Carrying out investigations in psychology: Methods and statistics, The British Psychological Society, Leicester.

Heijmans, M., Rijken, M., Foets, M., De Ridder, D., Schreurs, K. \& Bensing, J., 2004, 'The stress of being chronically ill: From disease-specific to task-specific aspects', Journal of Behavioral Medicine 27, 255-271.

Lazarus, R.S., 1993, 'Coping theory and research: Past, present and future', Psychosomatic Medicine 55, 234-247.

Lazarus, R.S. \& Folkman, S., 1987, 'Transtheoretical theory and research on emotions and coping', European Journal of Personality 1, 141-169.

Madhu, K. \& Sridhar, G.R., 2001, 'Coping with diabetes: A paradigm for coping with chronic illness', International Journal of Diabetes in Developing Countries 21, 103-111.

Moos, R.H., 1993, 'Coping Responses Inventory: CRI-Adult form professional manual, Psychological Assessment Resource Inc., Odessa, FL.

Moos, R.H. \& Holahan, C.J., 2003, 'Dispositional and contextual perspectives on coping: Toward an integrative framework', Journal of Clinical Psychology 59, 1387-1403.
Roglic, G., Unwin, N., Bennett, P.H., Mathers, C., Tuomiletho, J., Nag, S., Connolly, V. \& King, H., 2005, 'The burden of mortality attributable to diabetes', Diabetes Care 28, 2130-2135

Rose, M., Fliege, H., Hildebrandt, M., Schirop, T. \& Klapp, B.F., 2002, "The network of psychological variables in patients with diabetes and their importance for quality of life and metabolic control', Diabetes Care 25, 35-42.

Rowley, C., 1999, Factors influencing patient adherence in diabetes, University of Calgary, Alberta.

Sacco, W.P. \& Yanover, T., 2006, 'Diabetes and depression: The role of social support and medical symptoms', Journal of Behavioral Medicine 29, 523-531.

SAS Institute 2003, SAS User's Guide: Statistics Version 8.2 edn., SAS Institute, Cary.

Snellman, I. \& Wikblad, K., 2006, 'Health in patients with Type 2 diabetes: An interview study based on the Welfare Theory of Health', Scandinavian Journal of Caring Science 20, 462-471.

Sperry, L., 2006, Psychological treatment of chronic illness: The biopsychosocial therapy approach, American Psychological Association, Washington DC, WA.

Spollett, G.R., 2006, 'Type 2 diabetes across the life span', in C. Mensing (ed.), The Art and Science of Diabetes Self-Management Education: A Desk Reference for Healthcare Professionals, pp. 215-231, American Association of Diabetes Educators, Chicago.

Sridhar, G.R. \& Madhu, K., 2002, 'Psychosocial and cultural issues in diabetes mellitus', Current Science 83, 1556-1564.

Sriram, V., Sridhar, G.R. \& Madhu, K., 2001, 'Gender differences in living with type 2 diabetes', International Journal of Diabetes in Developing Countries 21, 97-102.

Steyn, H.S., 1999, Practical significance: The use of effect sizes, PU for CHE, Potchefstroom.

Willoughby, D.F., Kee, C.C., Demi, A. \& Parker, V., 2000, 'Coping and psychosocial adjustment of women with diabetes', The Diabetes Educator 26, 105-112. 